\title{
New Opportunities for the Digital Economy: the Implementation of an Effective State Innovation Policy
}

\author{
Andrey Petrovich Garnov ${ }^{1 *}$, Victoria Yuryevna Garnova ${ }^{1}$, Larisa Vladimirovna Shabaltina ${ }^{1}$, \\ Ildar Rustamovich Begishev ${ }^{2}$, Liya Vitalievna Panferova ${ }^{3}$
}

\author{
${ }^{1}$ Plekhanov Russian University of Economics, Russian Federation \\ ${ }^{2}$ Kazan Innovative University named after V.G. Timiryasov (IEML), Russian Federation
}

${ }^{3}$ Ulianov Chuvash State University, Russian Federation

Received: 06/01/2020

Accepted: 13/04/2020

Published: 20/09/2020

\begin{abstract}
Digital transformation is most often considered in theory and practice without taking into account the peculiarities of economic development, the action of economic trends, political and economic laws. The need to connect the needs of the population with the capabilities of the digital economy as a new technology is obvious, but the fact that digital transformation contributes, on the one hand, to development and progress, and on the other, the emergence of negative processes, the danger of which makes its introduction ambiguous, is also beyond doubt. The study reveals new opportunities for the digital economy of Russia in the context of the implementation of the Strategy for the Development of the Information Society. The article reveals the experience of leading countries that have achieved the greatest results in the development and implementation of effective state innovation economic policies; and how it can be used in shaping Russian regional innovation policies. The authors draw attention to the factors limiting the country's economic growth and ways to overcome this restriction, and propose to form a new mobilization model for managing the digital economy, developed on the basis of domestic digital technologies, transparent processes for their implementation.
\end{abstract}

Keywords: Digital economy, Information society, Development strategy, Economic growth, Innovative development, Digital technologies, Mobilization model

\section{Introduction}

The high level of development of information technologies in the modern economy has led to a change in the institutional conditions for the creation of digital assets. Against the background of unconditional improvement in the performance of almost all areas of the economy in which digital assets are increasingly used, therefore, a number of problems arise that need to be resolved in a timely manner. Nowadays, Russia also faces the challenge of creating a new management model based on digital technologies developed by domestic scientists and practitioners, as well as ensuring transparent processes for their implementation (1-3). At the same time, according to leading economists, constructing a new economic model while maintaining the existing type of economic development is not possible, since there are growth limits due to the limitations of traditional factors of production. This limitation is caused not only by the "flight of capital", "brain drain", the export of raw materials abroad, but, first of all, by the lack of own financial resources necessary for investing. Experts are trying to overcome these constraints by attracting foreign investment, which, in our opinion, cannot ensure the creation of our own "breakthrough" innovations and technologies, and enter the top five strongest economies in the world (4-9).

\section{Literature review}

The concept of the digital economy has many interpretations. The term "digital economy" was first used back in 1995 in the Don Tapscott's book "Digital economy: promise and danger in the age of network exploration". Currently, the essence of the digital economy is being considered simplistically ("smart cities", "smart homes", "artificial intelligence", in the field of education and healthcare - the creation of a service based on digital technologies and cost savings), believing that robots can replace humans. Officially, the beginning of the "shift" to the digital government in the domestic practice of public administration is associated with the adoption of the "Strategy for the Development of the Information Society in the Russian Federation for 2017-2030," which, "in order to provide conditions for the formation of a knowledge society in the Russian Federation, is supposed to be achieved through the shift from e-government to digital one", and the national program "Digital Economy of the Russian Federation" (2018 - 2024)", aimed at "improving the availability and quality of goods and services produced in the digital economy using modern digital technologies, the degree of education and digital literacy, the quality of public services for citizens, as well as enhancing security both within the country and abroad" (20).

Corresponding author: Andrey Petrovich Garnov, Plekhanov Russian University of Economics, Russian Federation. E-mail: prodanova-00@mail.ru 


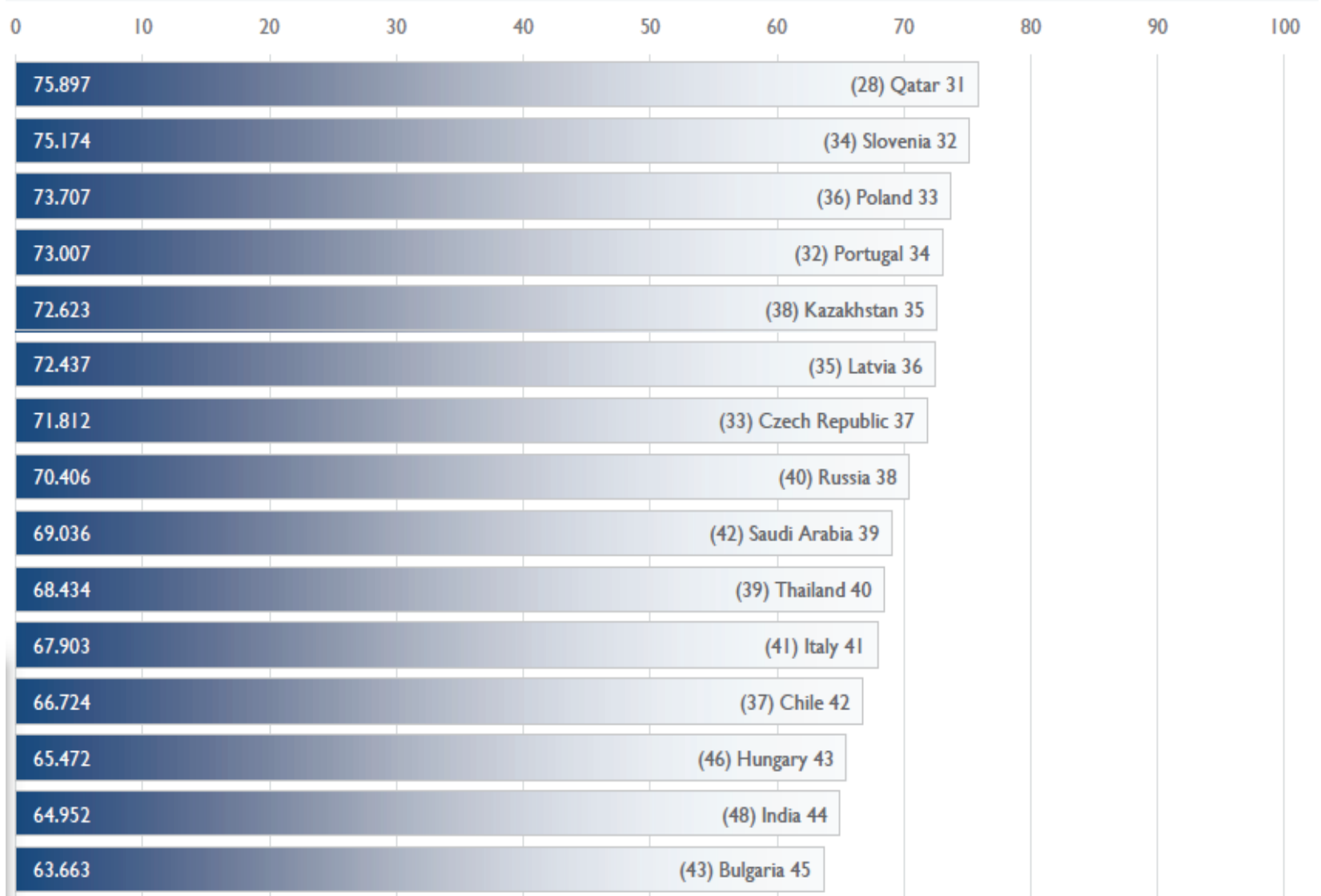

Figure 1: The world rating of digital competitiveness on a 100-point scale, compiled annually by the Swiss International Institute for Management and Development in Lausanne (positions 1-16)

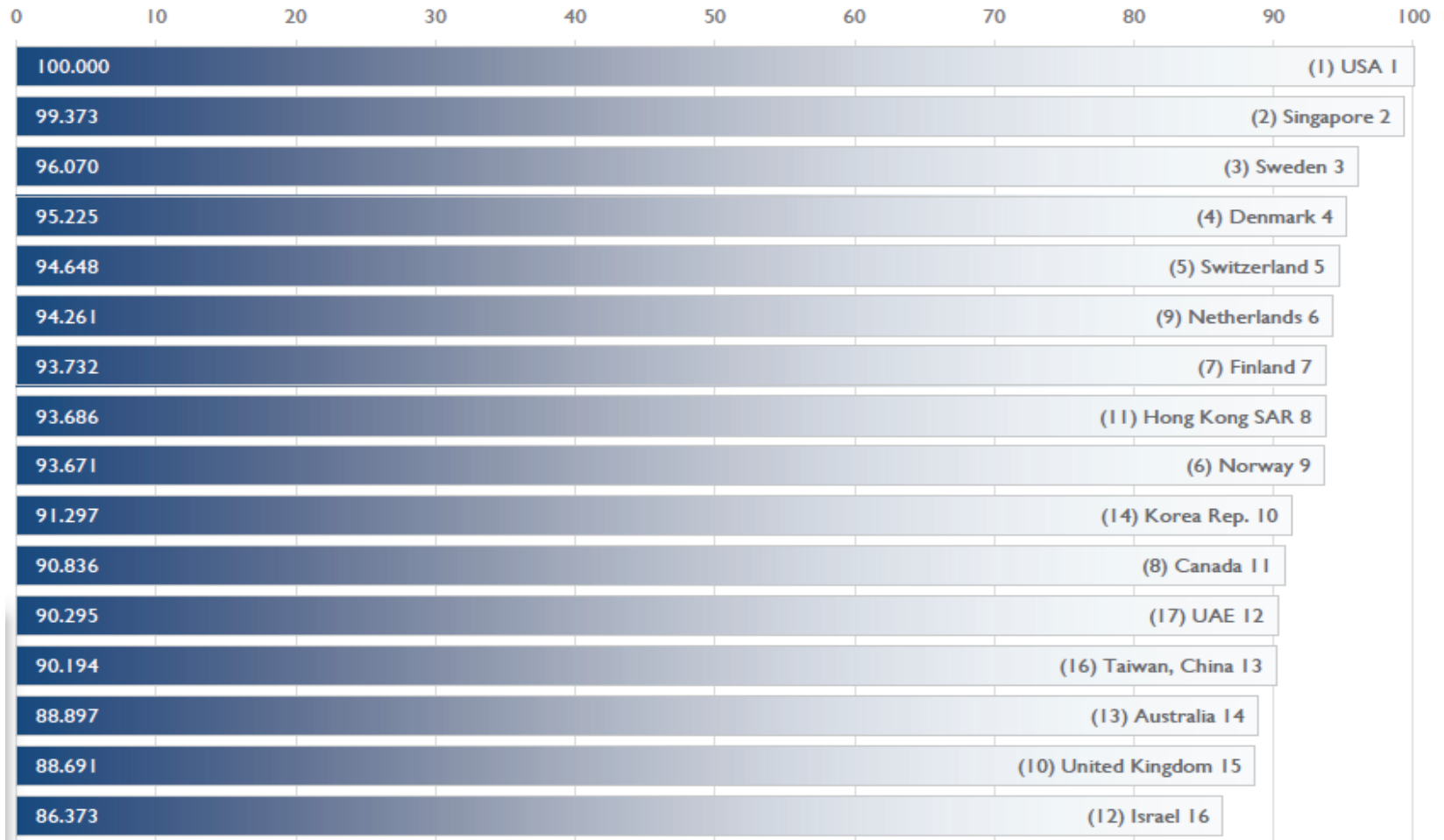

Figure 2: The world rating of digital competitiveness on a 100-point scale, compiled annually by the Swiss International Institute for Management and Development in Lausanne (positions 31-45) 


\section{Materials and methods}

The main research toolkit used in the work is a system analysis. To study theoretical and practical materials, empirical research methods, principles of formal logic, synthesis and analysis of the works of Russian and foreign scientists were applied.

\section{Results}

At present, Russia is not among the leaders in the development of the digital economy. According to the Rosstat, only a few percent of those employed in the economy, worked in the profession related to information and communication technologies, $36 \%$ of which are under the age of 30 . For example, in Germany, about $10 \%$ of the population is employed in high-tech industries (10-16). Nevertheless, the share of the digital economy in the country's GDP in recent years grew to 1.8 trillion rubles and reached $2.22 \%$. The authorities, apparently realizing the national importance of these objectives, are trying to mobilize resources on a national scale to solve them. The Global Digital Competitiveness Ranking, compiled annually by the Swiss International Institute for Management and Development in Lausanne, gives an idea of the position of the Russian Federation on the world stage on the implementation of digital technologies (fig.1, 2). In 2019, Russia rose from 40th to 38th place in the ranking of digital competitiveness of large economies, compiled by the Swiss business school IMD (Institute for Management Development). The neighbors of the Russian Federation by rating this year were the Czech Republic and Saudi Arabia. A total of 63 countries were rated. IMD assessment is based on 50 criteria, bundled into three main groups: knowledge, technology and readiness for the future. Quantitative criteria account for twothirds of their total weight, and one-third for polls. 19 out of 50 criteria are unique, the rest are borrowed from the overall competitiveness rating of IMD. The five digital leaders remained unchanged, these are: the USA, Singapore, Sweden, Denmark and Switzerland.

The volume of the US digital economy is $11 \%$ of GDP. They were able to put on the stream the production of innovations and their successful implementation in many areas of activity. Meanwhile, both the state and private companies are actively investing in advanced technologies. The experience of China, which economy also occupies an increasingly significant place in the digital economy of the world, is interesting. Thus, recently, the share of the main sectors of the digital economy in China has remained at the level of $6-7 \%$ of GDP. It is forecasted, that, by the end of 2020 , the volume of China's digital economy will exceed 32 trillion yuan and will amount to $35 \%$ of GDP, and by 2030, its share in GDP will exceed $50 \%$. At the same time, China ranks third in the world in terms of venture capital in various sectors of the economy (after the United States and Great Britain). In order to further stimulate this process, the Chinese government has unveiled a strategy for the development of artificial intelligence technologies, which aims to accelerate the development of not only artificial intelligence, but also the introduction of other relevant end-to-end digital technologies (Big data, quantum computing, industrial robotics, virtual and augmented reality technologies, etc.). China is ahead of everyone in the number of patents in the field of artificial intelligence - it accounts for $53 \%$ of all patents in this field, the US $-27 \%$, Japan $-6 \%$, Russia - less than $1 \%$.

Threats of regular technological accidents and the disintegration of the entire production base of the economy pose new problems of mechanisms for updating production factors. Among them, the depreciation fund is the most important. The absence of a depreciation fund and the law on limiting accelerated depreciation, contributes to its inclusion in costs, which significantly "accelerates" the production price, and capital assets necessary for not only development, but also for functioning, are withdrawn from economic turnover. Not only all depreciation deductions, but also most of the investments themselves, the deficit of which is increasing in the country, are "excluded" and "consumed" from active production turnover.

Of particular interest to science and economic practice are the laws of rational use of the labor force of society. During the period of creation and expansion of the digital economy, society is in dire need, but not yet ready for decisive changes in the use of labor. Innovative development leads to great difficulties in the redistribution of labor between sectors, regions and sectors of the economy, where extremely diverse interests of various economic entities are intertwined (17). Similar problems have occurred in different periods in other countries. The 40-year history of reforms in China allows us to speak about the accumulated experience and the possibility of studying it for our country. This experience shows that the active role of the state and its political openness, stimulating the development of science, patent relations with enterprises, and new elements in the education system have enabled the country, without deviating from its strategic goals, to modernize the old economic model into a model based on innovation. It was called the "New Normality", where the main "norm" is the use of Chinese science to improve lives of most people.

China's state strategy is designed primarily to increase welfare, and then to increase profits. China's citizen-oriented social system contributes to social progress. This is confirmed by the actions of recent years: tax rates have been reduced, average wages have been raised several times, and investments in education, healthcare, and culture have been expanded. A program on facilitating the transformation of science and technology into productive forces was adopted in 2016. In it, the level of education in the country is the main factor in increasing its competitiveness. According to experts, China has reached the sixth technological stage earlier than other countries $(18,19)$.

\section{Conclusion}

Analysis of the experience of countries that actively use digital transformation elements reveals not only competitive advantages in development, but also problems and disadvantages of these processes that should be taken into account when implementing them in the Russian Federation. To make it happen, not in words, but in reality, digital technologies must "serve" the entire society, but not its individual groups, estates, and clans. It is clear that the solution of economic problems with the help of digital technologies cannot by itself eliminate the disproportion of economic development, that is, to harmonize socially necessary needs and production possibilities (20-25). But information technologies are able to create technological support for solving targets. Currently, the real digital economy is being superseded by a virtual one based on the spontaneous use of digital technologies. The development of the "mobilization digital economy" requires the creation of a single platform of rules that guarantee the security and sovereignty of Russia. We do not have a mobilization model yet, threats are escalating and the time of missed opportunities is working for our competitors. These strategic tasks should come to the fore, form mechanisms for the transition from stage to stage, and link commoditymoney relations with planning based on an interdisciplinary research and scientific approach. In each of the constituent 
entities of the Russian Federation, the process of innovative development has its own characteristics, determined by the sectorial structure of the economy, the level of scientific and technological development, human potential in the field of science and innovation, and other specific features. At a conference in Dzerzhinsk with the involvement of representatives of the Ministry of digital development, communications and mass communications of the Russian Federation, and then at the conference "Digital transformation of regions", the "Guidelines for the development and implementation of programs for digital development of the economy of the Russian Federation subjects" were approved. According to these recommendations, regional programs will be considered as components of the Federal program "Digital economy of the Russian Federation". They should consist of projects corresponding to the directions of the federal program. In addition, regional programs may contain an additional section aimed at digitally transforming priority sectors of the economy and social sphere of a particular region by introducing digital technologies and platform solutions. This favourably distinguishes regional programs from the Federal ones, because regions will have the opportunity to develop projects in the real sector of the economy, which is not stipulated in the federal program. Organizational and technological solutions to create an effective infrastructure for the digital economy encounter contradictions that slow down integration processes. Innovative transformations, so far, serve a limited number of individuals, although their results should be delivered to the whole society. Large-scale transformations can only be achieved by the state acting on behalf of and in the interests of the entire society. Moving to a new mobilization model involves using not only modern ("fashionable") concepts, but also the knowledge that was formed on the basis of economic laws discovered by the classics.

\section{Ethical issue}

Authors are aware of, and comply with, best practice in publication ethics specifically with regard to authorship (avoidance of guest authorship), dual submission, manipulation of figures, competing interests and compliance with policies on research ethics. Authors adhere to publication requirements that submitted work is original and has not been published elsewhere in any language.

\section{Competing interests}

The authors declare that there is no conflict of interest that would prejudice the impartiality of this scientific work.

\section{Authors' contribution}

All authors of this study have a complete contribution for data collection, data analyses and manuscript writing.

\section{References}

1. Dunets AN, Yankovskaya V, Plisova AB, Mikhailova MV, Vakhrushev IB, Aleshko RA. Health tourism in low mountains: A case study. Entrepreneurship and Sustainability Issues. 2020;7(3):2213-27. doi:10.9770/jesi.2020.7.3(50)

2. Dunets AN, Vakhrushev IB, Sukhova MG, Sokolov MS, Utkina KM, Shichiyakh RA. Selection of strategic priorities for sustainable development of tourism in a mountain region: concentration of tourist infrastructure or nature-oriented tourism. Entrepreneurship and Sustainability Issues. 2019;7(2):1217-29. doi:10.9770/jesi.2019.7.2(29)

3. Turgaeva AA, Kashirskaya LV, Zurnadzhyants YA, Latysheva OA, Pustokhina IV, Sevbitov AV. Assessment of the financial security of insurance companies in the organization of internal control. Entrepreneurship and Sustainability Issues. 2020;7(3):2243-54. doi:10.9770/jesi.2020.7.3(52)
4. Tarasov VI. Technological and economic prospects and regulatory support for the production and sale of Russian biofuels. Industrialist of Russia. 2008;9.

5. Aleksandrovich LV, Pavlovna KP, Kimovich TI, Sergeevich TD. Development of smart well units for multilayer reservoirs operated with the system of simultaneous-separate exploitation. Journal of Applied Engineering Science. 2018;16(4):561-4. doi:10.5937/jaes16-17676

6. Almeida MVDA, Silva EMD, Gomes N, Nunes LAO, Curi W.F. Environmental quality of campina grande landfill based on technical and operational aspects. (Qualidade ambiental do aterro sanitário de campina grande com base em aspectos técnicos e operacionais) Periodico Tche Quimica. 2019;16(32):77-86.

7. Chen T, Babanin A, Al-Qāsim MA, Chapron B, Chen J, Md SH. Prototype of web-based daily work report management system using smart pens. Journal of Applied Engineering Science. 2019;17(3):280-3

8. Tica S, Živanović P, Bajčetić S, Milovanović B, Nađ A. Study of the fuel efficiency and ecological aspects of CNG buses in urban public transport in Belgrade. Journal of Applied Engineering Science. 2019;17(1):65-73.

9. Ivanova TS, Malarev VI, Kopteva AV, Koptev VY. Development of a power transformer residual life diagnostic system based on fuzzy logic methods. InJournal of Physics: Conference Series 2019 Nov (Vol. 1353, No. 1, p. 012099). IOP Publishing. doi:10.1088/1742-6596/1353/1/012099

10. Chupin S, Bolobov V. Influence of thermomechanical treatment modes on wear resistance of mining equipment material. InMaterials Science Forum 2019 (Vol. 945, pp. 695-699). Trans Tech Publications doi:10.4028/www.scientific.net/MSF.945.695

11. Ferreira APM, Teixeira EJN, Oliveira IMD, Pinheiro HDA, Marques ALB. New voltammetric method for determination of phenanthrene in groundwater. (Novo método voltamétrico para determinação de fenantreno em água subterrânea) Periodico Tche Quimica. 2019;16(33):169-177.

12. Filatova I, Shabalov M, Nikolaichuk L. Regulation methods in natural monopoly markets case of russian gas network companies. International Journal of Engineering Research and Technology. 2019;12(5):624-30.

13. Bondarenko A, Islamov S, Mardashov D. Features of oil well killing in abnormal carbonate reservoirs operating conditions. InEngineering and Mining Geophysics 2019 15th Conference and Exhibition 2019 Apr 16 (Vol. 2019, No. 1, pp. 1-5). European Association of Geoscientists \& Engineers.

14. Yemelyanov V, Tochilkina T, Vasilieva E, Nedelkin A, Shved E. Computer diagnostics of the torpedo ladle cars. InAIP Conference Proceedings 2018 Oct 31 (Vol. 2034, No. 1, p. 020008). AIP Publishing LLC. doi:10.1063/1.5067351.

15. Prischepa O, Nefedov Y, Grokhotov E. Geochemical and petrophysical studies of hydrocarbon potential of domanic shale formation (timan-pechora petroleum province). InEAGE/SPE Workshop on Shale Science 20192019 Apr 8 (Vol. 2019, No. 1, pp. 1-5). European Association of Geoscientists \& Engineers.

16. Jafarpour H, Moghadasi J, Khormali A, Petrakov DG, Ashena R Increasing the stimulation efficiency of heterogeneous carbonate reservoirs by developing a multi-bached acid system. Journal of Petroleum Science and Engineering. 2019, Jan 1;172:50-9. doi:10.1016/j.petrol.2018.09.034

17. Podoprigora DG, Korobov GY, Bondarenko AV. Acid stimulation technology for wells drilled the low-permeable high-temperature terrigenous reservoirs with high carbonate content. International Journal of Civil Engineering and Technology. 2019; 10(1):268096.

18. Movchan IB, Yakovleva AA. Refined assessment of seismic microzonation with a priori data optimisation. Записки Горного института. 2019; 236. doi:10.31897/PMI.2019.2.133

19. Aleksandrova TN, Nikolaeva NV, Potemkin VA. Beneficiation of carbonaceous rocks: New methods and materials. InInnovationBased Development of the Mineral Resources Sector: Challenges and Prospects-11th Conference of the Russian-German Raw Materials 2018 Oct 11 (pp. 391-398).

20. Dunyan $\mathrm{Ch}$. The current state of the digital economy in China and the prospects for cooperation between China and Russia in the field of the digital economy. Authority. 2017; 93. 
21. Puryaev, A. About the Essence of Categories "Efficiency" and "Efficiency of the Investment Project." In Smart Innovation, Systems and Technologies (Vol. 172, 2020, .pp. 643-651). Springer, Singapore. doi: 10.1007/978-981-15-2244-4_60

22. Kuzmin, P. A., Bukharina, I. L., \& Kuzmina, A. M. The reaction of woody plants to growing conditions in the man-made environment. International Journal of Civil Engineering and Technology, 2018, 9(11), 878-887.

23. Kuzhaeva, A.A., Dzhevaga, N.V., \& Berlinskii, I.V.. The processes of hydrocarbon conversion using catalytic systems. Journal of Physics: Conference Series, 2019, 1399(2),022057

24. Prischepa, O. M., Nefedov, Y. V., \& Kochneva, O. E.. Raw material base of hard-to-extract oil reserves of russia. [Matériaprima base de reservas de óleo de difícil extração da Rússia] Periodico Tche Quimica, 2020, 17(34), 915-924.

25. Zhadovskiy, I.T., Berlinskiy, I.V., Vasiliev, V.V., Stogov, A.V.. Influence of the content of caluminate on their physicochemical properties. Journal of Physics: Conference Series, 2019, 1384(1),012072 